${ }^{1}$ Asst. Prof., PhD.,

Anadolu University, Eskişehir, Turkey, satlama@anadolu.edu.tr

ORCID: 0000-0002-4224-6100

Submitted: $19 / 04 / 2021$

Revised: $28 / 05 / 2021$

Accepted: 7/06/2021

Online Published: 25/06/2021

Citation: Küçüksakarya, S., A panel causality analysis of the relationship between financial development and economic growth in OECD countries, bmij (2021) 9 (2): 662-672, doi:

https://doi.org/10.15295/bmij.v9i2.1817

\section{A panel causality analysis of the relationship between financial development and economic growth in OECD countries}

\author{
OECD üyesi ülkelerde finansal gelişme ve ekonomik büyüme \\ ilişkisinin panel nedensellik analizi
}

\author{
Sevilay Küçüksakarya ${ }^{1}$
}

\begin{abstract}
This study examines the relationship between financial development and economic growth. Thus, this study aims to find empirical shreds of evidence for the direction of the causality between financial development proxied by domestic credit to the private sector and per capita GDP growth by using the panel granger causality test of the Dumitrescu-Hurlin Test. For this purpose, we used a panel of 16 OECD countries from 2008 to 2019 to provide evidence of whether the supply leading hypothesis or demand following hypothesis or both holds. All econometric exercises are carried out for whole countries and high-income countries, and upper-middle-income country groups in the sample. Due to cross-sectional dependence among the sample countries, we determine the degree of integration of each variable by employing the second-generation panel unit root tests of CIPS. We continue our analysis with the panel causality test developed by Dumitrescu and Hurlin (2012) to determine the direction of the causality between variables. For this purpose, we performed three sets of causality analyses. In the first one, we include all countries in the panel. We then divided the countries into two sub-groups based on the income classification and the level of financial development in these countries proxied by domestic credit to the private sector. The causality test results, including all countries in the sample, indicate that the hypothesis holds the supply leading hypothesis during the sample period. This means that even though this panel contains countries with a development level, financial development still seems to be a pre-condition for economic growth for these nations. We also obtain the same results when we include high-income countries in the sample. The study results provide compelling evidence for the relationship between economic growth and financial development since the sample includes countries with different levels of financial development with different degrees of per capita GDP growth.
\end{abstract}

Keywords: Financial Development, Economic Growth, Cross-sectional Dependence, Second Generation Panel Unit Root Tests, Panel Cointegration, Panel Causality

Jel Codes: C23, G15, O11, O16

Öz

Bu çalışma, finansal gelişme ile ekonomik büyüme arasındaki ilişkiyi incelemektedir. Çalışmada, Dumitrescu Hurlin Testinin panel granger nedensellik testini kullanarak, finansal gelişme ile kişi başına GSYİH büyümesi arasındaki nedenselliğin yönüne ilişkin ampirik kanıtlar bulmak amaçlanmıştır. Bu amaçla, 2008-2019 dönemi için 16 OECD ülkesinden oluşan bir panel kullanılmıştır. Analizler 16 OECD ülkesinin tamımı için yapıldığı gibi; bu grupta yer alan gelişmiş ve gelişmekte olan ülkeler için de tekrarlanmıştır. Bu sayede arz öncüllü hipotezin mi yoksa talep takipli hipotezin mi geçerliği olduğu araştırılmıştır. Analizlerde önce ülkeler arasında hem değişkenler için hem de model bazında yatay kesit bağımlılığının varlığı araştırılmış ve yatay kesit bağımlılığı nedeniyle, ikinci nesil panel birim kök testlerinden CIPS yardımıyla değişkenlerin bütünleşme dereceleri belirlenmiştir. Değişkenler arasındaki nedensel ilişkinin yönünü belirlemek için Dumitrescu-Hurlin (2012) tarafından geliştirilmiş panel nedensellik testi uygulanmıştır. Nedensellik test sonuçları alt ülke grupları itibariyle iki değişken arasında çift yönlü nedensellik gösterirken; yüksek gelir grubuna sahip ülkeler için arz öncüllü hipotezin geçerli olduğunu göstermektedir. Test sonuçları farklı ülke grupları ve tüm ülkeler söz konusu olduğunda farklı sonuçlar gösterdiği için politika önerileri de buna göre farklılaşacaktır.

Anahtar Kelimeler: Finansal Gelişme, Ekonomik Büyüme, Yatay Kesit Bağımlılığı, İkinci Nesil Panel Birim Kök Testleri, Panel Eşbütünleşme, Panel Nedensellik

JEL Kodlari: C23, G15, O11, O16 


\section{Introduction}

Financial development can be defined simply as the continuous improvement of financial efficiency in financial markets, financial institutions, and financial instruments (Patrick, 1966; King and Levine, 1993a). Thus, it is one of the crucial determinants of economic growth. The breadth of the scope of even this simple definition shows how broad the impact of financial development on economic growth is. Therefore, the impact of financial development on economic growth is still uncertain. For this reason, empirical studies periodically reexamine the relationship between financial development and economic growth. Whether financial development promotes economic growth or economic growth causes financial development to be a widely investigated topic in economics. Schumpeter's well-known study in 1911 is considered as the starting point for the research of this topic. Following the critical papers of King and Levine (1993 a,b), there has been an increase in the number of studies implemented to search this relationship: Robinson (1952), Goldsmith (1969), McKinnon (1973), King and Levine (1993a,b), Obsfeld (1994), Levine (1997), Neusser and Kugler (1998), Levine and Zervos (1996), Levine, Loayza and Beck (2000), Beck, Levine and Loyaza (2000).

Studies related to this topic have an essential future so that the studies are repeated based on the development of new methods and the availability of the new data. Moreover, different methods such as time series, cross-section data, and panel data econometric techniques have increased the number of studies related to this relationship. Besides using the new techniques and the new data, the relationship between financial development and economic growth should be renewed following global developments such as the 2008-9 global crisis since this kind of development can change the direction of causality established by existing studies in the field.

For this purpose, we tried to find new evidence related to the causality direction between two variables. Thus, this study aims to find empirical shreds of evidence for the causality between financial development proxied by domestic credit to the private sector and per capita GDP growth by using the panel granger causality test, the Dumitrescu-Hurlin Test. We used a panel of 16 OECD countries from 2008 to 2019 to provide evidence of whether the supply leading hypothesis or demand following hypothesis or both holds. We performed three sets of causality analyses. In the first one, we include the whole countries in the panel. We then divided the countries into two sub-groups based on the income classification and the level of financial development in these countries proxied by domestic credit to the private sector. The causality test results, including all countries in the sample, indicate that the hypothesis holds the supply leading hypothesis during the sample period. It means that even though this panel contains countries with a development level, financial development still seems to be a precondition for economic growth for these nations. We also obtain the same results when we include highincome countries in the sample.

On the other hand, we obtain different results for the countries considered upper-middle-income countries or emerging markets. The result for these countries indicates that there is bi-directional causality between financial development and per capita income, implying that both the demand following and the supply leading hypothesis for these countries. Therefore, it is evident that we cannot employ or suggest one size fits all policies for these countries based on the interactions between financial development and economic growth.

The rest of the paper organized as follows: In the second section, we reviewed the existing literature. The third section introduces the data used in the study and summarizes the preliminary data analysis. The fourth section explains the methodology, the fifth section presents and discusses the empirical results, and the last section concludes.

\section{Literature review}

When the economics literature is examined, although the common point of many studies is that financial development positively impacts economic growth, there are also alternative views. When we group the studies according to their results, examples of studies showing the existence of a positive and significant relationship between financial development and economic growth are Schumpeter (1911), Goldsmith (1969), Bencivenga and Smith (1991), Roubini and Sala-i Martin (1992), Bencivenga, Smith and Starr (1995), Levine and Zervos (1996), Levine (1997), Greenwood and Smith (1997), Kargbo and Adamu (2009), Hassan, Sanchez and Yu (2011) and Adu, Marbuah and Mensah (2013). Besides, De Gregorio and Guidotti (1995), Ujunwa and Salami (2010), Nili and Rastad (2007), Naceur and Ghazouani (2007), and Narayan and Narayan (2013) found an insignificant or negative relationship between financial development and economic growth in their studies. Also, according to authors such as Robinson (1952), Ram (1999) and Opoku, Ibrahim and Sare (2019), there is no relationship between these two. In addition 
to these, Rajan and Zingales (1998) and Manganelli and Popov (2013) found a nonlinear relation between financial development and economic growth.

Schumpeter (1911) states in his study that financial intermediaries and savings are provided between economic units. They manage risk and support economic growth by performing financial transactions. As a result of the study, he found that financial development affects economic growth. Patrick (1966) states that modern financial institutions emerged with investor demand and that meeting these demands contributes to financial development by providing economic growth. Another study on the relationship between financial development and economic growth belongs to Levine (1997). According to Levine (1997), there is a robust relationship between growth, improvements in capital distribution efficiency, and physical capital accumulation. Besides, they determined that financial development indicators predict growth indicators.

We can also group the studies by supporting the hypothesis of their findings. Extensive empirical work on financial development and economic growth in different countries included in the sample has conflicting results. McKinnon (1973), Shaw (1973), King and Levine (1993 a,b), Neusser and Kugler (1998), Levine et al. (2000), Akinlo and Egbetunde (2010), Osuala, Okereke and Nwansi (2013), Bayar, Kaya and Yildirim (2014), Bist (2018) support the 'finance-led growth hypothesis' or the 'supply-leading hypothesis' with their studies' findings. Under this hypothesis, financial development is significant and leads to economic growth. On the other hand, according to the 'growth-led finance hypothesis', or the 'demand-following hypothesis', the improvement of the real sector leads to the development of the financial sector. Robinson (1952), Friedman and Schwartz (1963), Goldsmith (1969), Jung (1986), Greenwood and Jovanovic (1990), Ang and McKibbin (2007), Akinlo and Akinlo (2009), Athanasios and Antonios (2012) show in countries where economic growth occurs, financial sector development follows this situation.

Studies examining the relationship between financial development and economic growth used different indicators or proxies for financial development and economic growth. Most of the indicators used for financial development are the ratio of broad money to GDP, the ratio of the bank credit to the private sector to GDP, domestic credit to GDP, etc. Studies also use either GDP growth rate of per capita GDP growth rate. As King and Levine (1993 a) have argued in their study, this indicator has a clear advantage over other financial development measures such as broad money to GDP ratio since it represents the actual volume of funds transferred to the private sector more accurately. Therefore, the ratio of domestic credit to the private sector to GDP is more directly linked to investment and economic growth (De Gregorio and Guidotti, 1995). For this reason, in this study, we prefer to use the ratio of domestic credit to the private sector (\% of GDP) to measure financial development.

Based on the literature review, it is evident that there is a need to examine the relationship of financial development to economic growth. Using the method that considers heterogeneity in the panel consists of countries with different developmental levels.

\section{Data and preliminary analysis}

This study analyses the relationship between financial development and economic growth for highincome countries and upper-middle-income countries between 2008-2019. In this context, OECD members eight high-income countries (Norway, Iceland, Australia, Japan, Denmark, USA, United Kingdom, Korea) and eight upper-middle-income countries (Czech Republic, Hungary, Israel, Mexico, Poland, Sweden, Turkey, Chile) were evaluated.

The empirical literature on the relationship between financial development and economic growth shows that studies have mainly used three different majors of financial development. These are the ratio of domestic credit to the private sector to GDP, IMF financial development index, the ratio of broad money such as M2 or M3 to GDP, the ratio of bank credit to the private sector to GDP. As De Gregorio and Guidotti (1995) mentioned, the ratio of domestic credit to the private sector to GDP has some advantages over other indicators among these three alternatives. Because this indicator is an accurate proxy for the actual volume of funds channelled to the private sector, it has more advantages than accurate interest rates or M1, M2, or M3 measures. Briefly, it is more directly linked to economic growth and investment. The growth indicator is the real per-capita GDP growth rate. In other words, the percentage increase in per capita national income representing economic growth was used as the dependent variable, and the share of the GDP\% of the loans granted to the private sector as an independent variable. We obtain the data for both variables from the World Bank Database (WDI). Table 1 defines the variables, and Table 2 displays summary statistics about the data. 
Table 1: Variables

\begin{tabular}{lll}
\hline $\begin{array}{l}\text { Domestic Credit to Private Sector (\% } \\
\text { Of GDP) }\end{array}$ & DCPSGDP & World Development Indicators \\
\hline Per Capita GDP Growth & PCGDPGROWTH & World Development Indicators \\
\hline
\end{tabular}

Table 2: Descriptive Statistics

\begin{tabular}{|l|c|c|c|c|c|c|}
\hline \multirow{2}{*}{} & \multicolumn{2}{|c|}{ Group A } & \multicolumn{2}{c|}{ Group B } & \multicolumn{2}{c|}{ Group C } \\
\cline { 2 - 7 } & DCPSGDP & $\begin{array}{c}\text { PCGDPGROW } \\
\text { TH }\end{array}$ & DCPSGDP & PCGDPGROWTH & DCPSGDP & PCGDPGROWTH \\
\hline Mean & 108.158 & 1.356 & 149.714 & 0.866 & 66.603 & 1.847 \\
\hline Median & 122.426 & 1.446 & 146.147 & 1.088 & 53.991 & 1.958 \\
\hline Maximum & 201.258 & 9.509 & 201.258 & 6.274 & 132.679 & 9.509 \\
\hline Minimum & 20.673 & -7.094 & 84.902 & -7.094 & 20.673 & -6.674 \\
\hline Std. Dev. & 51.445 & 2.461 & 27.991 & 2.000 & 32.364 & 2.774 \\
\hline Skewness & -0.039 & -0.718 & -0.2143 & -1.410 & 0.791 & -0.738 \\
\hline Kurtosis & 1.701 & 5.424 & 2.412 & 7.117 & 2.383 & 4.732 \\
\hline Jarque-Bera & 13.540 & 63.519 & 2.115 & 99.621 & 11.549 & 20.725 \\
\hline Probability & 0.001 & 0.000 & 0.347 & 0.000 & 0.000 & 0.000 \\
\hline Observation & 192 & 192 & 96 & 96 & 96 & 96 \\
\hline
\end{tabular}

As shown in Table 2, domestic credit to the private sector to GDP shows more volatility than the per capita GDP growth during the sample period implied by standard deviation. Also, the volatility of the ratio of domestic credit private sector to GDP is higher for upper-middle-income countries than highincome countries. Figure 1 shows a scatter diagram between the per capita GDP growth rates and domestic credits to the private sector for the whole panel.

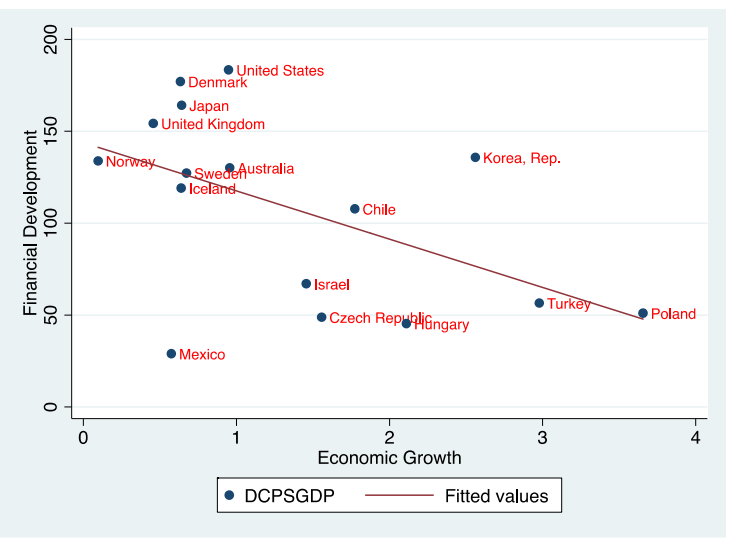

(a)

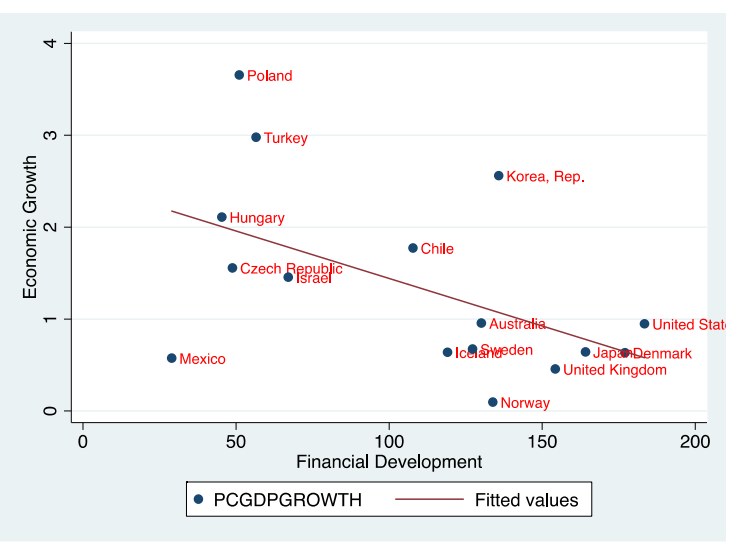

(b)

Figure 1: The Ratio of Domestic Credit to the Private Sector to GDP and per capita GDP Growth Rate for Whole Countries

Figure 1 shows that countries in the sample are divided into two groups in terms of financial development. In the first group, countries such as Norway, Iceland, Australia, Japan, Denmark, the USA, United Kingdom, and Korea show a high level of financial development but relatively low growth of per capita GDP except Korea Rep. On average they seem to be a homogenous relationship between economic growth and financial development for these countries. On the other hand, even though other countries seem to have an approximate level of financial development, there is high variability in 
economic growth. Mexico seems to have the lowest level of financial development and economic growth.

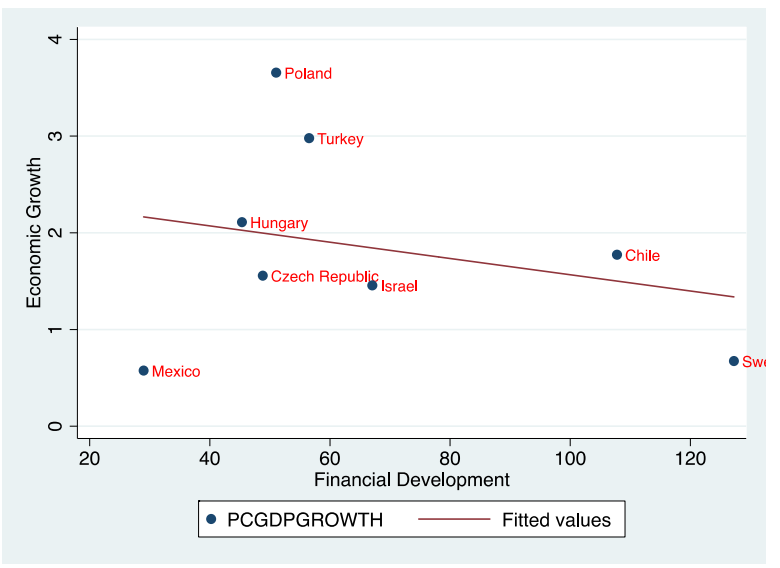

(a)

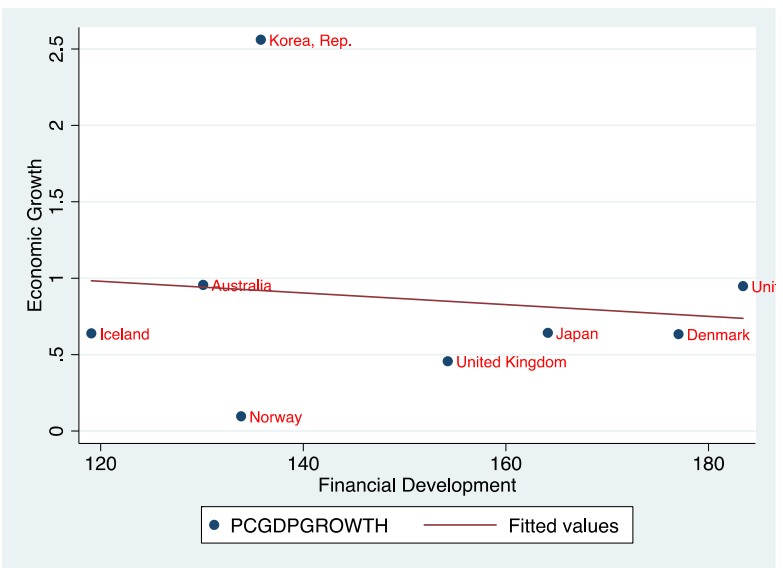

(b)

Figure 2: The Ratio of Domestic Credit to the Private Sector to GDP and per capita GDP growth rate for High Income and Upper Middle-Income Countries

Figure 2 includes two scatter diagrams of subgroups of the countries in the sample. Figure 2 part (a) displays the scatter diagram between economic and financial development of countries with a relatively lower financial development level than part $b$ representing the scatter diagrams of the countries with a relatively high level of financial development. Moreover, both scatter diagrams show an inverse relationship between financial development and economic growth.

Countries after reaching a certain level of financial development have a negative impact when the level of financial development increases. It causes the financial fragility. Since the sample countries have different levels of financial development and growth rates, the period averages show such an inverse relationship (Ductor and Grechyna, 2015). In other words, the impact of financial development on economic growth weakens as the financial market grows (Rajan and Zingales, 1996). Also, most of the sample countries during the sample period affected worst by the global financial crises of 2008 and European Debt crises. Therefore, it is not surprising to have the adverse effects of the financial system struggling with many problems on economic growth.

\section{Methodology}

To analyze the causal relationships between financial development and economic growth panel causality test developed by Dumitrescu and Hurlin (2012) was used. Before carrying out this test, we first tested the existence of cross-sectional dependence between variables employing Breusch-Pagan (1980) (Lagrange Multiplier-LM) and Pesaran (2004) (Cross-section Dependence-CD) and Pesaran, Ullah and Yamagata (2008) (Bias-Adjusted Cross Sectionally Dependence Lagrange Multiplier- CD LM) tests. And then, based on the results of the cross-sectional dependence tests, we performed second generation panel unit root tests of CIPS stands for Cross sectionally-augmented IPS (2003) test, to investigate the long-run relationship between financial development and economic growth. Before implementing the causality test, we carry out Westerlund error-correction-based panel cointegration tests developed by Westerlund (2007) to get evidence supporting the results of the panel causality tests. Finally, we applied the Dumitrescu-Hurlin (2012) Panel Causality Test.

As is well known, the Dumitrescu-Hurlin panel causality test is a simple adaptation of the Granger noncausality test for constant-coefficient non-homogeneous panel data models. In Dumitrescu and Hurlin (2012), the authors considered heterogeneity in terms of two dimensions, which are the heterogeneity of the regression model used to test Granger causality and the heterogeneity of causality relationships. In order to do this test, the series must be stationary at the same level. This method considers the crosssectional dependence among the countries in the sample (Dumitrescu and Hurlin, 2012).

The Dumitrescu-Hurlin test can predict cross-section dependence and cross-section independence situations. When we examine the traditional panel Granger causality tests, it can be seen that if there is a causal relationship in a sub-group of the variable, due to the lack of cross-sectional information, that is because of the homogeneous null hypothesis. The null hypothesis means that there is no Granger causality relationship in cross-sections, and the alternative hypothesis expresses a Granger causality relationship for at least one cross-section (Dumitrescu and Hurlin, 2012). 
Dumitrescu and Hurlin (2012) used the following equation for panel causality test considering the linear heterogeneous model:

$$
y_{i t}=\alpha_{i}+\sum_{k=1}^{L} \gamma_{i}^{k} y_{i t-k}+\sum_{k=1}^{L} \beta_{i}^{k} x_{i t-k}+\varepsilon_{i t}, \mathrm{i}=1,2, \ldots, \mathrm{N}: \mathrm{t}=1,2, \ldots, \mathrm{T}
$$

Where $\alpha_{i}$ denotes individual effects, $\gamma_{i}^{k}$ and $\beta_{i}^{k}$ represents the lag and slope parameters, and L supposed to be the lag orders. We can summarize the model's assumptions as; the individual effects are constant, besides the same lag length in cross-section, the coefficients of slope and lag parameters vary across units and especially a balance panel must be required for the Dumitrescu-Hurlin test. The null and alternative hypotheses equation are as follows:

$$
\begin{gathered}
H_{0}: \beta_{i 1}=\cdots=\beta_{i K}=0 \quad \forall_{i}=1, \ldots, N \\
H_{1}=\beta_{i 1}=\cdots=\beta_{i K}=0 \quad \forall_{i}=1, \ldots, N_{1} \\
\beta_{i 1} \neq 0 \text { or } \beta_{i K} \neq 0 \quad \forall_{i}=N_{1}+1, \ldots, N
\end{gathered}
$$

When we consider the null hypothesis, it can be seen that there is no Granger causality relationship between variables for all units. In contrast, the alternative hypothesis represents at least one unit that there is evidence of Granger causality between variables. Individual residues are independent for each cross-section unit. Therefore, while the alternative hypothesis supports heterogenous results, the null hypothesis is a heterogenous model providing homogenous results. This test is usually distributed and allows (Dumitrescu and Hurlin, 2012).

To determine the outcome of the Dumitrescu-Hurlin panel causality test hypotheses, one can use a test statistic, which is the mean of all test statistics of cross-sectional units.

$$
W_{N, T}^{H N C}=\frac{1}{N} \sum_{i=1}^{N} W_{i, T} \quad \text { (HNC: Homogeneous Non-Causality) }
$$

Where $\mathrm{W}_{\mathrm{i}, \mathrm{T}}$ represents the test statistics of each cross-sectional unit. In this test, one can obtain two different test statistics based on whether $\mathrm{T}$ is greater or less than $\mathrm{N}$. These test statistics are $Z_{N, T}^{H N C}$ and $Z_{N}^{H N C}$ obtained from $W_{N, T}^{H N C}$. When $\mathrm{T}>\mathrm{N}$, we use $Z_{N, T}^{H N C}$ statistics. On the otherhand if $\mathrm{T}<\mathrm{N}$ we use $Z_{N}^{H N C}$ statistics. Furthermore, the following equations give these statistics.

$$
\begin{gathered}
Z_{N, T}^{H N C}=\sqrt{\frac{N}{2 K}}\left(W_{N, T}^{H N C}-K\right) \quad \mathrm{T}, \mathrm{N} \rightarrow \infty, \mathrm{N}(0,1) \\
Z_{N}^{H N C}=\frac{\sqrt{N}\left(W_{N, T}^{H N C}-N^{-1} \sum_{i=1}^{N} E\left(W_{i, T}\right)\right.}{\sqrt{N^{-1} \sum_{i=1}^{N} \operatorname{Var}\left(W_{i, T}\right)}} \quad \mathrm{N} \rightarrow \infty, \mathrm{N}(0,1)
\end{gathered}
$$

Where $E\left(W_{i, T}\right)$ and $\operatorname{Var}\left(W_{i, T}\right)$ denotes the mean and the variance of $\mathrm{W}_{\mathrm{i}, \mathrm{T}}$ respectively, if there is a crosssectional dependence, we use the critical table values at a $5 \%$ level of significance obtained from 50000 iterations (Dumitrescu and Hurlin, 2012: 8-10).

\section{Empirical results}

We start testing cross-sectional dependence among the countries to analyze the causal relationship between economic growth and financial development. For this purpose, we use three different crosssectional dependence tests, which are the Lagrange Multiplier-LM test of Breusch-Pagan (1980), Crosssection Dependence-CD test of Pesaran (2004) and Bias-Adjusted Cross Sectionally Dependence Lagrange Multiplier- $\mathrm{CD}_{\mathrm{LM}}$ test of Pesaran et al. (2008). Table 3 presents the results of these tests. 
Table 3: The Results of the Cross-Sectional Dependence Tests

\begin{tabular}{|c|c|c|c|c|c|c|c|c|c|}
\hline \multirow{2}{*}{$\begin{array}{l}\text { Test/ } \\
\text { Varia } \\
\text { bles }\end{array}$} & \multicolumn{3}{|c|}{ Group A } & \multicolumn{3}{|c|}{ Group B } & \multicolumn{3}{|c|}{ Group C } \\
\hline & $\begin{array}{c}\text { PCGDP } \\
\text { GROWT } \\
\text { H }\end{array}$ & $\begin{array}{c}\text { DCPS } \\
\text { GDP }\end{array}$ & Model & $\begin{array}{c}\text { PCGD } \\
\text { PGRO } \\
\text { WTH }\end{array}$ & $\begin{array}{l}\text { DCPS } \\
\text { GDP }\end{array}$ & Model & $\begin{array}{c}\text { PCGD } \\
\text { PGRO } \\
\text { WTH }\end{array}$ & $\begin{array}{c}\text { DCPS } \\
\text { GDP }\end{array}$ & Model \\
\hline $\mathrm{CD}_{\mathrm{BP}}$ & $\begin{array}{l}541.852 \\
(0.0000)\end{array}$ & $\begin{array}{l}763.168 \\
(0.0000)\end{array}$ & $\begin{array}{l}532.169 \\
(0.0000)\end{array}$ & $\begin{array}{l}143.521 \\
(0.0000)\end{array}$ & $\begin{array}{l}133.657 \\
(0.0000)\end{array}$ & $\begin{array}{l}110.982 \\
(0.0000)\end{array}$ & $\begin{array}{l}122.189 \\
(0.0000)\end{array}$ & $\begin{array}{l}236.170 \\
(0.0000)\end{array}$ & $\begin{array}{l}129.513 \\
(0.0000)\end{array}$ \\
\hline$C D_{L M}$ & $\begin{array}{r}27.230 \\
(0.0000)\end{array}$ & $\begin{array}{c}41.516 \\
(0.0000)\end{array}$ & $\begin{array}{r}26.605 \\
(0.0000)\end{array}$ & $\begin{array}{c}15.437 \\
(0.0000)\end{array}$ & $\begin{array}{c}14.119 \\
(0.0000)\end{array}$ & $\begin{array}{c}11.088 \\
(0.0000)\end{array}$ & $\begin{array}{c}12.586 \\
(0.0000)\end{array}$ & $\begin{array}{c}27.817 \\
(0.0000)\end{array}$ & $\begin{array}{r}13.565 \\
(0.0000)\end{array}$ \\
\hline $\mathbf{L M}_{\mathbf{a d j}}$ & $\begin{array}{l}26.503 \\
(0.0000)\end{array}$ & $\begin{array}{r}40.789 \\
(0.0000)\end{array}$ & $\begin{array}{r}25.878 \\
(0.0000)\end{array}$ & $\begin{array}{c}15.073 \\
(0.0000)\end{array}$ & $\begin{array}{c}13.755 \\
(0.0000)\end{array}$ & $\begin{array}{c}10.725 \\
(0.0000)\end{array}$ & $\begin{array}{c}12.222 \\
(0.0000)\end{array}$ & $\begin{array}{c}27.454 \\
(0.0000)\end{array}$ & $\begin{array}{c}13.201 \\
(0.0000)\end{array}$ \\
\hline CD & $\begin{array}{l}21.047 \\
(0.0000)\end{array}$ & $\begin{array}{c}0.801 \\
(0.4077)\end{array}$ & $\begin{array}{l}21.182 \\
(0.0000)\end{array}$ & $\begin{array}{c}10.958 \\
(0.0000)\end{array}$ & $\begin{array}{c}1.129 \\
(0.2589)\end{array}$ & $\begin{array}{c}9.355 \\
(0.0000)\end{array}$ & $\begin{array}{c}10.042 \\
(0.0000)\end{array}$ & $\begin{array}{c}2.161 \\
(0.0307)\end{array}$ & $\begin{array}{c}10.507 \\
(0.0000)\end{array}$ \\
\hline \multicolumn{10}{|c|}{$\begin{array}{l}\text { Note: Numbers in parenthesis are p-values of the test statistics. } \\
{ }^{*} \text { Indicates the rejection of the null hypothesis of cross-sectional independence (CD test) and the null hypothesis of unit } \\
\text { root at a } 1 \% \text { significance level. The test regression is fitted with a constant. } \\
\text { Group A: Whole countries. } \\
\text { Group B: High-Income Countries (Norway, Iceland, Australia, Japan, Denmark, USA, United Kingdom, Korea) } \\
\text { Group C: Upper-middle-income Countries (Czech Republic, Hungary, Israel, Mexico, Poland, Sweden, Turkey, Chile) }\end{array}$} \\
\hline
\end{tabular}

The results of all cross-sectional dependence tests indicate a cross-sectional dependence among the countries in terms of both variables implying that shocks to any variable will have a potential spread to other countries. Because of the cross-sectional dependence, we carry out second-generation panel unit root tests of the cross-sectional augmented panel unit root IPS (CIPS) test developed by Pesaran, Smith and Yamagata (2013) to determine the degree of the integration of each variable. Table 4 shows these results.

Table 4: The Results of Panel Unit Root Test

\begin{tabular}{|c|c|c|c|c|c|c|c|c|c|}
\hline \multirow[b]{3}{*}{ Variables } & \multicolumn{3}{|c|}{ Group A } & \multicolumn{3}{|c|}{ Group B } & \multicolumn{3}{|c|}{ Group C } \\
\hline & \multicolumn{9}{|c|}{ CIPS (intercept) } \\
\hline & Level & 1st diff. & Result & level & 1st diff. & Result & level & 1st diff. & Result \\
\hline DCPSGDP & -2.106 & $-3.024^{*}$ & $\mathrm{I}(1)$ & -2.188 & $-3.241^{*}$ & $\mathrm{I}(1)$ & -1.551 & $-2.697^{*}$ & $\mathrm{I}(1)$ \\
\hline PCGDPGROWTH & $-2.695^{*}$ & $-4.147^{*}$ & $\mathrm{I}(1)$ & $-3.742^{*}$ & $-4.076^{*}$ & $\mathrm{I}(1)$ & -2.011 & $-3.601^{*}$ & $\mathrm{I}(1)$ \\
\hline \multicolumn{10}{|c|}{$\begin{array}{l}\text { Note: *denotes rejection of the null hypothesis of no cointegration at } 1 \% \text { significance level. } \\
\text { Table critical values at } 10 \%, 5 \% \text { and } 1 \% \text { significance level are: (for Group A)- 2.11, -2.22, -2.45 ; (for Group B and C)- 2.22,-2.37,-2.66 } \\
\text { (Pesaran, 2007). } \\
\text { Numbers in parenthesis are p-values of the test statistics. } \\
\text { Group A: Whole countries. } \\
\text { Group B: High-Income Countries (Norway, Iceland, Australia, Japan, Denmark, USA, United Kingdom, Korea) } \\
\text { Group C: Upper-middle-income Countries (Czech Republic, Hungary, Israel, Mexico, Poland, Sweden, Turkey, Chile) }\end{array}$} \\
\hline
\end{tabular}

As is seen in Table 4, all test results indicate that domestic credit to private is the first difference stationary that is $\mathrm{I}(1)$. Nevertheless, the unit root test results regarding the level and first differences stationarity of variable provide mixed results. We reject the null hypotheses when we test both the series are level and first difference. Therefore, to determine the degree of the integration of the PCGDPGROWTH, we followed the suggestion of Granger (2010) and Iheonu, Asongu, Odo and Ojiem. 
(2020). Also, to show the robustness of causality test results, we use the suggestion made by Andriansyah and Messinis (2019). Following their suggestion, we first test the existence of cointegration between two variables by using Westerlund error-correction-based panel cointegration tests, which considers cross-sectional dependence. Table 5 presents the results of this test.

Table 5: The Results of Cointegration Tests

\begin{tabular}{|c|c|c|c|c|c|c|c|c|c|c|c|c|}
\hline \multirow{2}{*}{$\begin{array}{l}\text { Groups/ } \\
\text { Statistic }\end{array}$} & \multicolumn{3}{|c|}{$\mathrm{G}_{\mathrm{T}}$} & \multicolumn{3}{|c|}{$\mathrm{G}_{\mathbf{a}}$} & \multicolumn{3}{|c|}{$\mathbf{P}_{\mathrm{T}}$} & \multicolumn{3}{|c|}{$\mathbf{P}_{a}$} \\
\hline & Value & $\begin{array}{c}\text { Z- } \\
\text { value }\end{array}$ & $\begin{array}{c}\text { P- } \\
\text { value }\end{array}$ & Value & $\begin{array}{c}\text { Z- } \\
\text { value }\end{array}$ & $\begin{array}{c}\text { P- } \\
\text { value }\end{array}$ & Value & $\begin{array}{c}\text { Z- } \\
\text { value }\end{array}$ & $\begin{array}{c}\mathrm{P}- \\
\text { value }\end{array}$ & Value & $\begin{array}{c}\text { Z- } \\
\text { value }\end{array}$ & $\begin{array}{c}\mathrm{P}- \\
\text { value }\end{array}$ \\
\hline Group A & -5.92 & -18.45 & 0.000 & -6.01 & 0.83 & 0.793 & -16.87 & -11.14 & 0.000 & -7.75 & -3.17 & 0.001 \\
\hline Group B & -7.72 & -18.71 & 0.000 & -3.47 & 1.90 & 0.977 & -14.21 & $\begin{array}{l}-10.18 \\
\end{array}$ & 0.000 & -11.02 & -4.33 & 0.000 \\
\hline Group C & -4.12 & -7.38 & 0.000 & -8.55 & -0.73 & 0.231 & -11.15 & -7.10 & 0.000 & -6.77 & -1.62 & 0.053 \\
\hline \multicolumn{13}{|c|}{$\begin{array}{l}\text { Note: In Westerlund error-correction-based panel cointegration test, the null hypothesis states no cointegration. While } G_{\mathrm{T}} \text { and } \\
\mathrm{G}_{\mathrm{a}} \text { are groups mean statistics to test the null hypothesis of no cointegration against the alternative hypothesis of cointegration } \\
\text { among some of the selected countries, } P_{\mathrm{T}} \text { and } \mathrm{P}_{\mathrm{a}} \text { are the panel statistics to test the null of no cointegration against the alternative } \\
\text { hypothesis of cointegration among whole countries. }\end{array}$} \\
\hline
\end{tabular}

Since there is cointegration between the variables, this should be considered an indication of causality between variables. Thus, regardless of the degree of the integration of the variables, one can rely on the results of the panel granger causality test of Dumitrescu-Hurlin and Table 6, including these tests' results.

Table 6: The Results of Dumitrescu-Hurlin Causality Tests

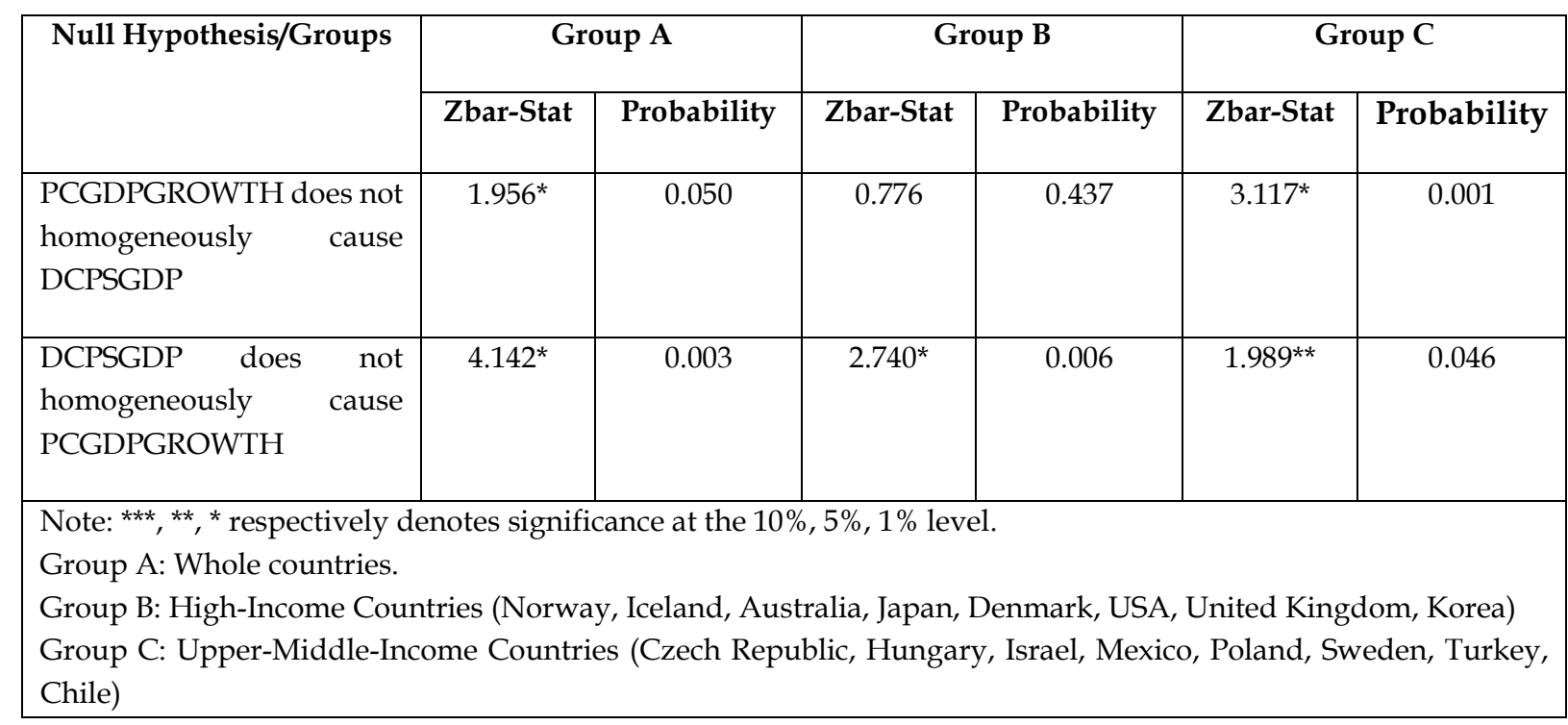

Based on the test results, we conclude that there is bi-directional Granger causality between the economic growth and financial development for whole countries (Group A), implying that both supply leading and demand following hypothesis hold for these countries. Since we observe an apparent heterogeneity among the sample countries regarding financial development and economic growth, we repeat the same tests for the countries' subgroups. The results for high-income countries (Group B) with a high level of financial development show a unidirectional causality running from financial development to economic growth, implying that the supply leading hypothesis holds for these countries. Because except for the United States, all other countries have adopted a money market-leddevelopment strategy. We obtained the same bi-directional causality for the upper-middle-income countries (Group C) as well. Therefore, we concluded that both supply leading and demand following hypothesis hold for these countries. Since the countries in these groups are using a mix of money and stock market-led development policies, these results should be seen as plausible results. 


\section{Conclusion}

This paper examines the causal relationship between economic growth and financial development for some OECD countries using the panel causality test developed by Dumitrescu-Hurlin. The study results provide some interesting evidence for the relationship between economic growth and financial development since the sample includes countries with different levels of financial development with different degrees of per capita GDP growth. First of all, results show a cross-sectional dependence among the countries regarding both variables implying that shocks to any variable will potentially spread to other countries. Second, we found causality for the whole panel that there is bi-directional granger causality between the economic growth and financial development, implying that both supply leading and demand following hypothesis hold for the countries in the sample. Third, there is a unidirectional causality running from financial development to economic growth for the group of highincome countries, implying that the supply leading hypothesis holds for these countries. There is bidirectional causality between economic growth and financial development for the upper-middleincome countries, implying that both supply leading and demand following hypothesis hold for these countries.

Based on the results of the study, we can reach the following conclusions and make policy suggestions. To increase the per capita GDP to growth rates, these countries still need to adopt policies that organize the financial system, allowing domestic credits to the private sector. Second, since upper-middle-income countries in the sample are examples of the countries exhibited by the directional causality, these countries need to understand that aiming to policies most designed to increase economic growth will also promote financial development. For this purpose, the size and efficiency of the banking system can be increased to create more credit to the private sector. Because of this banking system in most of these countries should be carefully monitored and supported.

\section{Peer-review:}

Externally peer-reviewed

\section{Conflict of interests:}

The author(s) has (have) no conflict of interest to declare.

\section{Grant Support:}

The authors declared that this study has received no financial support

\section{References}

Adu, G., G. Marbuah, \& J. T. Mensah. (2013). Financial Development and Economic Growth in Ghana: Does the Measure of Financial Development Matter? Review of Development Finance 3:192-203.

Andriansyah, A., \& Messinis, G. (2019). Stock prices, exchange rates and portfolio equity flows: A TodaYamamoto panel causality test. Journal of Economic Studies.

Ang, J. B., \& McKibbin, W. J. (2007). Financial liberalization, financial sector development and growth: evidence from Malaysia. Journal of development economics,84(1), 215-233.

Akinlo, A. E., \& Akinlo, O. O. (2009). Stock Market Development and Economic Growth: Evidence from Seven Sub-Sahara African Countries. Journal of Economics and Business 61 (2):162-71. Search in Google Scholar

Akinlo, A. E., \& Egbetunde, T. (2010). Financial development and economic growth: The experience of 10 sub-Saharan African countries revisited. The review of finance and banking, 2(1).

Athanasios, V., \& Antonios, A. (2012). Stock market development and economic growth an empirical analysis for Greece. American Journal of Economics and Business Administration, 4(2), 135.

Bayar, Y., Kaya, A., \& Yildirim, M. (2014). Effects of stock market development on economic growth: Evidence from Turkey. International Journal of Financial Research, 5(1), 93. 
Beck T., Levine R. \& Loyaza N. (2000). Finance and the sources of growth. J. Financ. Econ., 58: 261-300.

Bencivenga V.R. \& Smith B.D. (1991). Financial development and endogenous growth. Rev. Econ. Stud., 58: 195-209

Bencivenga V., Smith B. \& Starr R. (1995). Transaction costs, technological choice and endogenous growth. J. Econ. Theory, 67: 153-177.

Bist, J. P. (2018). Financial development and economic growth: Evidence from a panel of 16 African and non-African low-income countries. Cogent Economics \& Finance, 6(1), 1449780.

Breusch, T.S \& Pagan, A.R. (1980). The Lagrange Multiplier Test and Its Applications to Model Specification Tests in Econometrics. Review of Economic Studies, 47, 239-53.

De Gregorio, Jose, \& Pablo E. Guidotti. (1995). Financial development and economic growth. World development, Vol 23 (3), 433-448.

Demetriades, P. O., \& Hussein, K. A. (1996). Does financial development cause economic growth? Timeseries evidence from 16 countries. Journal of development Economics, 51(2), 387-411.

Ductor, L., \& Grechyna, D. (2015). Financial development, real sector, and economic growth. International Review of Economics \& Finance, 37, 393-405.

Dumitrescu, E. I., \& Hurlin, C. (2012). Testing for Granger Non-Causality In Heterogeneous Panels. Economic Modelling, 29 (4): 1450-1460.

Goldsmith R.W. (1969). Financial structure and development. (CT Yale Univesity Press, New Haven).

Granger, C. W. (2010). Some thoughts on the development of cointegration. Journal of Econometrics, 158(1), 3-6.

Greenwood J. \& Jovanovic B (1990). Financial development, growth, and the distribution of income. J. Polit. Econ., 98: 1076-1107.

Greenwood J. \& Smith B.D. (1997). Financial markets in development and the development of financial markets. J. Econ. Dyn. Control, 21: 145- 181.

Hassan, M. K., Sanchez, B., \& Yu, J. S. (2011). Financial development and economic growth: New evidence from panel data. The Quarterly Review of economics and finance, 51(1), 88-104.

Iheonu, C. O., Asongu, S. A., Odo, K. O., \& Ojiem, P. K. (2020). Financial sector development and Investment in selected countries of the Economic Community of West African States: empirical evidence using heterogeneous panel data method. Financial Innovation, 6(1), 1-15.

Im, K. S., Pesaran, M. H., \& Shin, Y. (1997). Testing for Unit Roots in Heterogenous Panels. DAE, Working Paper 9526, University of Cambridge.

Im K.S., Pesaran M.H., \& Shin Y. (2003). Testing for unit roots in heterogeneous panels, Journal of Econometrics, 115 pp. 53-74

Jung WS (1986). Financial development and economic growth: international evidence. Econ. Dev. Cultural Change, 34: 336-346.

Kargbo, S. M., \&. Adamu P. A. (2009). Financial Development and Economic Growth in Sierra Leone. West African Journal of Monetary and Economic Integration 9 (2):30-61.

King RG, Levine R (1993a). Finance and growth: Schumpeter might be right. Quart. J. Econ., 108: 717738.

King RG, Levine R (1993b). Finance, entrepreneurship and growth: theory and evidence. J. Monetary Econ., 32: 513-542.

Levine R (1997). Financial development and economic growth: views and agenda. J. Econ. Lit., 35: 688726.

Levine R. \& Zervos S. (1996). Stock market development and long-run growth. World Bank Econ. Rev., 10: 323-339.

Levine R., Loayza N. \& Beck T (2000). Financial intermediation and growth: causality and causes. J. Monetary Econ., 46: 31-77

Maddala G.S., \&Wu S.A. (1999) Comparative study of unit root tests with panel data and a new simple test, Oxford Bulletin of Economics and Statistics, 108 (1999), pp. 1-24. 
Manganelli, S., \& Popov, A. (2013). Financial dependence, global growth opportunities, and growth revisited. Economics Letters, 120(1), 123-125.

McKinnon RI (1973). Money and capital in economic development. (Brookings Institution, Washington, $\mathrm{DC})$.

Naceur, S. B., \& Ghazouani, S. (2007). Stock markets, banks, and economic growth: Empirical evidence from the MENA region. Research in International Business and Finance, 21(2), 297-315.

Narayan, P. K., \& Narayan, S. (2013). The short-run relationship between the financial system and economic growth: New evidence from regional panels. International Review of Financial Analysis, 29, 70-78.

Neusser K,. \& Kugler M (1998). Manufacturing growth and financial development: evidence from OECD countries. Rev. Econ. Stat., 80: 638-646.

Obstfeld M (1994). Risk-taking, global diversification, and growth. Am. Econ. Rev., 84: 1310-1329.

Opoku, E. E. O., Ibrahim, M., \& Sare, Y. A. (2019). The causal relationship between financial development and economic growth in Africa. International Review of Applied Economics, 33(6), 789-812.

Osuala, A. E., Okereke, J. E., \& Nwansi, G. U. (2013). Does stock market development promote economic growth in emerging markets? A causality evidence from Nigeria. World Review of Business Research, 3(4), 1-13.

Patrick H. T. (1966)., Financial Development and Economic Growth in Underdeveloped Countries, Economic Development and Cultural Change, 14 (1), pp. 174- 189.

Pesaran, M.H. (2004). General Diagnostic Tests for Cross Section Dependence in Panels, Cambridge

Working Papers in Economics, 435.

Pesaran, M.H. (2007). A simple Panel Unit Root Test in the Presence of Cross-section Dependence, J. Appl. Econ., 22 , 265-312.

Pesaran, M. H., Ullah, A., \& Yamagata, T. (2008). A bias-adjusted LM test of error cross-section independence. The Econometrics Journal, 11(1), 105-127.

Pesaran M. H., Smith, L. V. and Yamagata, T. (2013). Panel unit root tests in the presence of a multifactor error structure, Journal of Econometrics, Vol. 175, pp. 94- 115.

Puatwoe, J. T., \& Piabuo, S. M. (2017). Financial sector development and economic growth: evidence from Cameroon. Financial Innovation, 3(1), 1-18.

Rajan, R. G., \& Zingales, L. (1996). Financial dependence and growth (No. w5758). National bureau of economic research.

Ram R. (1999). Financial Development and Economic Growth: Additional Evidence, Journal of Development Studies, 35 (4), pp. 164- 174.

Robinson J. (1952). The generalization of the general theory. In: The Rate of Interest and Other Essays. (MacMillan, London).

Roubini, N. \& Sala-i Martin, X. (1992), 'Financial Repression and Economic Growth', Journal of Development Economics, 39, 5-30.

Schumpeter J.A. (1911). The theory of economic development. (Harvard University Press, Cambridge, MA).

Shaw E.S. (1973). Financial deepening in economic development. (Oxford University Press, London).

Ujunwa, A., \& Salami, O. P. (2010). Stock market development and economic growth: Evidence from Nigeria. European Journal of Economics, Finance and Administrative Sciences, 25, 44-53. 